\title{
Salicylic Acid Alleviates Aluminum Toxicity in Tomato Seedlings (Lycopersicum esculentum Mill.) through Activation of Antioxidant Defense System and Proline Biosynthesis
}

\author{
Varalakshmi Surapu, Anjaneyulu Ediga, Balaji Meriga* \\ Department of Biochemistry, Sri Venkateswara University, Tirupati, India \\ Email: ${ }^{*}$ balaji.meriga@gmail.com
}

Received 12 June 2014; revised 15 July 2014; accepted 18 August 2014

Copyright (C) 2014 by authors and Scientific Research Publishing Inc.

This work is licensed under the Creative Commons Attribution International License (CC BY).

http://creativecommons.org/licenses/by/4.0/

(c) (i) Open Access

\section{Abstract}

The aim of this work was to evaluate the alleviating efficacy of salicylic acid $(100,250$ and $500 \mu \mathrm{M})$ against the toxic effects of aluminum (Al) on two tomato cultivars (GOWRI and SIRI) differing in their sensitivity to Al stress. Al treatment $(500 \mu \mathrm{M})$ caused $40 \%-80 \%$ drop in plant growth, relative water content (RWC) and cell viability and a reduction of $1-2.5$ fold and $0.5-2$ fold in glutathione and proline content respectively, when compared to their control plants grown in $\mathrm{Al}$ free medium. Al treatment also resulted in 2 - 5 fold raise in malondialdehyde (MDA) levels, 2 - 3 fold higher Al uptake and 55\% - 80\% more electrolyte leakage and caused severe DNA damage. Al stress enhanced (1 - 2 fold) the activities of superoxide dismutase (SOD) and peroxidase (POD), but decreased catalase (CAT) activity over their respective controls. Exogenously-applied Salicylic acid (SA) significantly $(p<0.05)$ and dose-dependently alleviated Al-induced toxicity in tomato seedlings as marked by much improved plant growth, retention of higher RWC, cell viability, glutathione and proline content. SA also caused 0.6 - 1.5 fold reduction in Al uptake, $50 \%-80 \%$ less electrolyte leakage, $40 \%-80 \%$ drop in lipid peroxidation and considerable protection against DNA damage. Also, supplementation of SA could considerably reverse the $\mathrm{Al}$-induced changes in the activities of SOD, POD and CAT. Together, our findings demonstrate that, SA is an efficient growth regulator with diversified roles that contribute to its potential alleviating effect against $\mathrm{Al}$ induced toxicity and SIRI is a relatively Al-resistant cultivar compared to GOWRI.

${ }^{*}$ Corresponding author.

How to cite this paper: Surapu, V., Ediga, A. and Meriga, B. (2014) Salicylic Acid Alleviates Aluminum Toxicity in Tomato Seedlings (Lycopersicum esculentum Mill.) through Activation of Antioxidant Defense System and Proline Biosynthesis. Advances in Bioscience and Biotechnology, 5, 777-789. http://dx.doi.org/10.4236/abb.2014.59091 
Keywords

Aluminum, Antioxidant Enzymes, Proline, Malondialdehyde, Salicylic Acid

\section{Introduction}

Aluminum (Al) is the most abundant metal in the earth's crust and a major constraint to crop yield in acidic soils which constitute about $50 \%$ of the world's potentially arable land [1]. The problem of acidic soils is further aggravated by high usage of ammonium fertilizers, mining activities and industrial development, in addition to certain natural processes. To meet the increasing demand of food for the rapidly increasing population, we need to extend our farming land as well as improve productivity. Tomato is one of the most commonly used vegetables across the world and India is the 3rd largest producer of Tomato. The major tomato growing states in India are Maharastra, Andhrapradesh, Karnatak, Tamil Nadu, Gujarath and U.P. Although, tomato is widely grown, one of the limiting factors for its yield is aluminium stress and acidic soils. Hence, studies related to understanding the molecular mechanisms associated with $\mathrm{Al}$ toxicity and tolerance in tomato will be of great relevance for growing tomato crop in acid soils.

When the soil pH falls below 5.0, $\mathrm{Al}$ speciates into its ionic forms, among which $\mathrm{Al}^{3+}$ is the most toxic form. Apart from $\mathrm{Al}^{3+}$ cation, $\mathrm{Al}$ has the potential to form hydroxyl-Al and polynuclear species in solution. The primary target of Al toxicity is the root tip in which $\mathrm{Al}$ causes inhibition of cell elongation and cell division leading to stunted root system resulting in poor ion and water uptake [2]. Al toxicity also causes leaf chlorosis and retarded plant growth. At cellular level the targets of Al include cell wall, plasma membrane, cytoskeleton and nucleus [1]-[3]. At molecular level, $\mathrm{Al}^{3+}$ binds with oxygen donor molecules such as proteins, phospholipids, polysaccharides, nucleic acids, carboxylic acids, etc. and triggers an increased production of reactive oxygen species (ROS) which include singlet oxygen $\left({ }^{1} \mathrm{O}_{2}\right)$, superoxide radical $\left(\mathrm{O}_{2}\right)$, hydroxyl radical $(\mathrm{OH})$, and hydrogen peroxide $\left(\mathrm{H}_{2} \mathrm{O}_{2}\right)$ in the tissue. These ROS cause oxidative damage to cellular organelles and biomolecules and thus lead to several metabolic alterations [3] [4]. More particularly, the oxidative damage caused due to ROS leads to peroxidation of proteins, membrane lipids that may cause loss of plasma membrane integrity and leakage of ions and sometimes DNA damage too. To keep the cellular level of ROS under control and to avoid oxidative damage, plant system is endowed with antioxidant system which include ascorbic acid, glutathione, carotenoids as well as free radical scavenging enzymes such as superoxide dismutase (SOD, EC 1.15.1.1), catalase (CAT, EC 1.11.1.6), and peroxidase (POD, EC 1.11.1.7) [5]. Malondialdehyde (MDA) is an ultimate product formed as a result of lipid peroxidation and its concentration expresses the degree of membrane peroxidation and consequent damage. Therefore, the examination of antioxidant enzyme activities and MDA content often serve as a key biochemical indicator to assess the sensitivity of plants under stress conditions [6].

Different plant species exhibit distinct variations in regard to sensitivity and/or tolerance to $\mathrm{Al}^{3+}$. Mechanisms of Al tolerance have been broadly classified as those which prevent $\mathrm{Al}$ uptake by roots and those which detoxify the already accumulated $\mathrm{Al}$ in the cell. Tolerant plants have evolved mechanisms to detoxify $\mathrm{Al}$ present both internally and externally [7]. To achieve internal detoxification, plants accumulate and sequester $\mathrm{Al}$ inside the vacuoles where it chelates with organic acids such as citrate, malate, oxaloacetate or any such other substance and maintains in non-toxic or less toxic form [7]. Another mechanism by which plants exhibit tolerance to $\mathrm{Al}$ is by exudation of certain acids through roots which may form a protective shield over root surface and protect the root system from toxic effects of $\mathrm{Al}^{3+}$ [1]. Proline is thought to play a cardinal role as an osmoregulatory solute in plants subjected to hyper osmotic stresses, primarily water deficit and soil salinity. Indeed, the accumulation of this amino acid may be part of a general adaptation to several environmental stresses including exposure to $\mathrm{Al}$. Since plants subjected to Al stress undergo similar physiological changes as that of plants exposed to drought stress, the role of proline is implicated as an adaptive measure to prevail upon such stress conditions. Proline stabilizes cellular structures as well as scavenges free radicals. Also, the identification of stress regulated genes provides new tools to overcome $\mathrm{Al}$ stress. Research continues to identify candidate genes that could play a role in alleviating $\mathrm{Al}$ stress in plants.

Salicylic acid is (SA) is an endogenous growth regulator of phenolic nature and it could be included in the category of phytohormones, which participates in the regulation of physiological processes in plants [8]. Ex- 
ogenous application of SA may influence a range of diverse processes in plants, including growth rate, stomatal closure, ion uptake and transport, membrane permeability and photosynthetic processes. There are experimental evidences indicating participation of SA in signal regulation of gene expression during leaf senescence in Arabidopsis. The alleviation of oxidative damage and increased resistance to environmental stresses is often correlated with an efficient anti-oxidative system [8].

We hypothesized that external supplementation of SA could differentially activate the antioxidant system and proline biosynthesis of resistant and sensitive tomato cultivars due to different internal and/or external detoxification systems and may lead to biochemical and physiological changes. In this study, we analyzed the effect of different concentrations of SA on growth parameters, certain biochemical and physiological aspects, antioxidant enzymes (SOD, POD, CAT), proline content and DNA damage in two tomato cultivars (SIRI and GOWRI) with different $\mathrm{Al}$ sensitivities.

\section{Materials and Methods}

\subsection{Plant Material and Treatment Conditions}

Tomato seeds were obtained from the Horticulture College and Research Institute, Railway Kodur, Kadapa district, A.P. After preliminary screening, two cultivars, viz., GOWRI and SIRI were identified as Al-sensitive and Al-resistant cultivars respectively. The seeds of these two cultivars were surface-sterilized and germinated in Petri plates. To study growth parameters and for other physiological and biochemical studies, seedlings with uniform root and shoot length were divided into different groups and grown in 1/10 strength Hoagland's solution ( $\mathrm{pH} 4.5)$ [9] containing $\mathrm{Al}(500 \mu \mathrm{M})$ or $\mathrm{Al}$ with different concentrations of SA $(100,250$ and $500 \mu \mathrm{M})$ for two weeks at $25^{\circ} \mathrm{C} \pm 2^{\circ} \mathrm{C}$ under $12 \mathrm{~h}$ light $\left(300 \mu \mathrm{M} \cdot \mathrm{m}^{-2} \cdot \mathrm{s}^{-1}\right)$-dark cycles and harvested for further analysis. Control plants were grown under same conditions in 1/10 strength Hoagland solution without Al. The treatment solutions were renewed every alternate day.

\subsection{Determination of Al Uptake and Relative Water Content}

Hematoxylin staining procedure was used to determine Al uptake [10]. Roots of seedlings were initially washed in distilled water for 20 min followed by staining with $0.2 \%$ aqueous hematoxylin solution containing $0.02 \%$ $\mathrm{KIO}_{3}$ for $20 \mathrm{~min}$ at room temperature and then washed with distilled water for 20 min. Root tips, 10 - 15 in number, were collected and soaked in $250 \mu \mathrm{L}$ of $1 \mathrm{M} \mathrm{HCl}$ for $1 \mathrm{~h}$. The optical density (OD) of released stain was measured at $490 \mathrm{~nm}$ using spectrophotometer (Perkin Elmer, USA) and Al uptake was calculated. RWC was determined according to the procedure of Smart and Bingham (1974) using the formula:

RWC $=($ fresh weight-dry weight/fresh weight $) \times 100$.

\subsection{Determination of Electrolyte Leakage, Lipid Peroxidation and Loss of Plasma Membrane Integrity}

Electrolyte leakage in leaf discs of control and treated seedlings was determined as described by Lin et al. [11] Leaf discs were incubated in double-distilled water (DDW) for $24 \mathrm{~h}$, and then the leakage of electrolytes into DDW was determined with the help of a conductivity meter (Jenway 4020).

Lipid peroxidation was determined by measuring the content of malondialdehyde (MDA) formed by the thiobarbituric acid reaction as described by Heath and Packer [12]. Leaves were ground with a pestle and mortar in 1\% TCA (10 mL·g ${ }^{-1}$ fresh weight) and centrifuged at 10,000 rpm for $5 \mathrm{~min}$. To $1.0 \mathrm{~mL}$ of supernatant in a separate test tube, $4.0 \mathrm{~mL}$ of $0.5 \%$ TBA was added. The mixture was heated at $95^{\circ} \mathrm{C}$ for $30 \mathrm{~min}$, then cooled in icecold water and later centrifuged at $5000 \mathrm{rpm}$ for $5 \mathrm{~min}$. Absorbance was measured at $532 \mathrm{~nm}$ and corrected for unspecific turbidity by subtracting the value at $600 \mathrm{~nm}$. The blank contained 1\% TBA in 20\% TCA. MDA content was calculated using an extinction coefficient of $155 \mathrm{~mm}^{-1} \cdot \mathrm{cm}^{-1}$.

Alterations in cell membrane integrity and cell viability during Al stress of tomato leaves was determined by Evans blue assay [13]. This cell viability assay is based on the uptake of Evans blue by nonviable cells. Briefly, leaf discs of control and treated seedlings were stained with $0.25 \%$ (v/v) Evans blue solution for $20 \mathrm{~min}$ followed by washing with distilled water for $30 \mathrm{~min}$. The dye bound to dead cells was solubilized in $50 \%$ (v/v) ethanol containing $1 \%(\mathrm{w} / \mathrm{v}) \mathrm{SDS}$, heated at $60^{\circ} \mathrm{C}$ for $30 \mathrm{~min}$ and quantified by reading absorbance at $600 \mathrm{~nm}$. An internal standard of heat-killed cells from leaf discs was used to determine the percentage of relative viability. 


\subsection{Determination of Glutathione and Proline Content}

To estimate glutathione content, leaf tissue (2.0 g) of control and treated tomato seedlings was homogenized in $3.0 \mathrm{~mL}$ of $0.1 \mathrm{~N} \mathrm{HCl}(\mathrm{pH} 2.0$ ) containing $1.0 \mathrm{~g}$ polyvinylpyrrolidone (PVP) followed by centrifugation at 10,000 $\mathrm{g}$ for $10 \mathrm{~min}$ at $4^{\circ} \mathrm{C}$ and the supernatant was used for analysis of total glutathione (reduced GSH plus oxidized GSSG). The supernatant was precipitated with $0.1 \mathrm{~N} \mathrm{HCl}$ using glutathione reductase, 5, 5'dithio-bis-(2-nitrobenzoic acid) (DTNB) and NADPH and the absorbance was read spectrophotometrically at $412 \mathrm{~nm}$. GSSG was determined by following the same method in the presence of 2-vinylpyridine, and the GSH concentration was measured from the difference between total glutathione and GSSG [14].

Proline content was measured as described by Bates et al. [15]. In brief, leaves (500 mg) of tomato seedlings were homogenized with sulphosalicylic acid and centrifuged at $5000 \mathrm{rpm}$. The supernatant was collected and the absorbance was measured at $520 \mathrm{~nm}$. Proline content was expressed as $\mu \mathrm{g} \cdot \mathrm{g}^{-1}$ fresh weight.

\subsection{Assay of Antioxidant Enzymes}

Fresh leaves $(0.5 \mathrm{~g})$ were homogenized with a mortar and pestle under chilled conditions with phosphate buffer (0.1 M, pH 7.5) and ethylene diamine tetra acetic acid (EDTA, $0.5 \mathrm{mM}$ ). The homogenate was filtered through muslin cloth and centrifuged at $12,000 \mathrm{~g}$ for $10 \mathrm{~min}$ at $4^{\circ} \mathrm{C}$. The resulting supernatant was used for the assay of said antioxidant enzymes.

Superoxide dismutase (SOD) activity was determined as described by Bayer and Fridovich [16] by measuring its ability to inhibit the photochemical reduction of nitroblue tetrazolium chloride (NBT). The assay mixture contained $1 \mathrm{~mL}$ of enzyme extract, $0.1 \mathrm{mM}$ phosphate buffer (pH 7.5), $3 \mathrm{mM} \mathrm{NBT}$ and $60 \mathrm{mM}$ riboflavin. The tubes were thoroughly shaken and placed under $15 \mathrm{~W}$ fluorescent lamp for $10 \mathrm{~min}$, then the lights were switched off and the tubes were covered with a black cloth. For the purpose of blank, the non-illuminated reaction mixture was used. Absorbance of the reaction mixture was read at $560 \mathrm{~nm}$ and one unit of SOD activity (EU) was defined as the amount of enzyme required to cause $50 \%$ inhibition of the NBT photo reduction rate. The results were expressed as units' mg-1 protein.

For the assay of peroxidase (POD), the method of Nakano and Asada [17] was followed. The assay mixture contained $1.0 \mathrm{~mL}$ of potassium phosphate (pH 7.0) buffer supplemented with $0.1 \mathrm{mM}$ EDTA, $0.5 \mathrm{mM}$ ascorbate, $0.1 \mathrm{mM} \mathrm{H}_{2} \mathrm{O}_{2}$ and $0.1 \mathrm{~mL}$ of enzyme extract. POD activity was measured in terms of decrease in absorbance at $290 \mathrm{~nm}$ of ascorbate and expressed as units $\mathrm{mg}^{-1}$ protein. For the calculation of POD activity, the extinction coefficient of $2.8 \mathrm{mM}^{-1} \cdot \mathrm{cm}^{-1}$ was used. One unit of enzyme activity was considered as the amount required for decomposing $1 \mu \mathrm{M}$ of substrate per min at $25^{\circ} \mathrm{C}$.

Catalase (CAT) activity was measured following the method of Aebi [18]. The assay mixture contained 0.1 $\mathrm{mL}$ of enzyme extract, $0.1 \mathrm{mM}$ phosphate buffer (pH 7.5), $0.1 \mathrm{M}$ EDTA, and $0.3 \% \mathrm{H}_{2} \mathrm{O}_{2}$ and the absorbance was measured at $240 \mathrm{~nm}$. CAT activity was expressed as units. $\mathrm{mg}^{-1}$ protein. For the calculation of CAT activity, the extinction coefficient of $0.036 \mathrm{mM}^{-1} \cdot \mathrm{cm}^{-1}$ was used.

\subsection{Isolation and Analysis of Nuclear DNA}

Nuclear DNA was isolated according to the protocol of Jena and Kochert [19]. DNA extraction buffer, (pH 8.0) contained $5 \mathrm{~mol} \cdot \mathrm{L}^{-1} \mathrm{NaCl}, 1 \mathrm{~mol} \cdot \mathrm{L}^{-1}$ Tris-HCl, $0.25 \mathrm{~mol}$ EDTA, $20 \%$ sarkosyl and phenol and $0.75 \mathrm{~mL}$ of SDS. After chloroform-amyl alcohol step and precipitating DNA with $70 \%$ alcohol, the sample was then treated with $15 \mu \mathrm{L}$ of DNAase-free RNAase $\left(10 \mathrm{mg} \cdot \mathrm{mL}^{-1}\right)$. Two $\mu$ g of DNA was subjected to electrophoresis on $0.8 \%$ agarose gel and the quality of DNA was observed.

\subsection{Statistical Analysis}

Experimental results are expressed as means \pm SD. All measurements were replicated six times. The data were analyzed by analysis of variance $(P<0.05)$ and the means were separated by Duncan's multiple range test.

\section{Results and Discussion}

\subsection{Growth Traits}

Inhibition of root length followed by shoot length is a visible and earliest symptom of Al toxicity. In the present 
study, when compared to control plants, plant growth of SIRI in terms of root and shoot lengths was significantly inhibited $(40 \%)$ in the presence of $500 \mu \mathrm{M} \mathrm{Al}$ concentration, while that of GOWRI was inhibited by $80 \%$. However, supplementation of SA to Al-containing solution substantially improved plant growth (65\% - 85\% in SIRI and 20\% - 55\% in GOWRI) in a dose-dependent manner (Figure 1(a)). Al-induced inhibition of root length indicates a marked increase in the uptake of $\mathrm{Al}$ by the roots grown in Al-containing solution. Spectrophotometric quantification of hematoxylin stain in root tips of both Al-treated tomato varieties revealed 2 - 3 fold increase of $\mathrm{Al}$ uptake when compared to controls. The presence of SA in the treatment medium lowered $\mathrm{Al}$ uptake by the roots. Both stain intensity and area declined considerably in root tips of $\mathrm{Al}+\mathrm{SA}$-treated seedlings compared to $\mathrm{Al}$ alone treated seedlings. Quantification of hematoxylin stain in root tips revealed that $500 \mu \mathrm{M}$ SA treatment prevented Al uptake (0.6 - 1.5 fold) by root tips better, compared to 100 and $250 \mu \mathrm{M}$ SA (Figure 1(B)). Our data showed that, RWC of GOWRI and SIRI declined substantially ( $70 \%$ and $30 \%$ respectively) in $\mathrm{Al}$ treated seedlings. However, exogenous supplementation of SA significantly restored $(60 \%-80 \%$ in SIRI and $35 \%-60 \%$ in GOWRI) RWC in tomato cultivars as shown in Figure 2(a). These results demonstrate that under $\mathrm{Al}$ stress, tomato seedlings experienced significant changes as follows: decreased RWC content; higher Al uptake leading to inhibition of root system and stunted growth due to inefficient nutrient uptake via root systems. These observations were more pronounced in GOWRI when compared to SIRI under Al stress. However, External supplementation of SA could substantially reverse these alterations, with SIRI showing better recovery than GOWRI under Al stress.

\subsection{Determination of Lipid Peroxidation, Cell Viability and Electrolyte Leakage}

Estimation of lipid peroxidation (MDA content) of membrane lipids, as well as electrolyte leakage often serve as

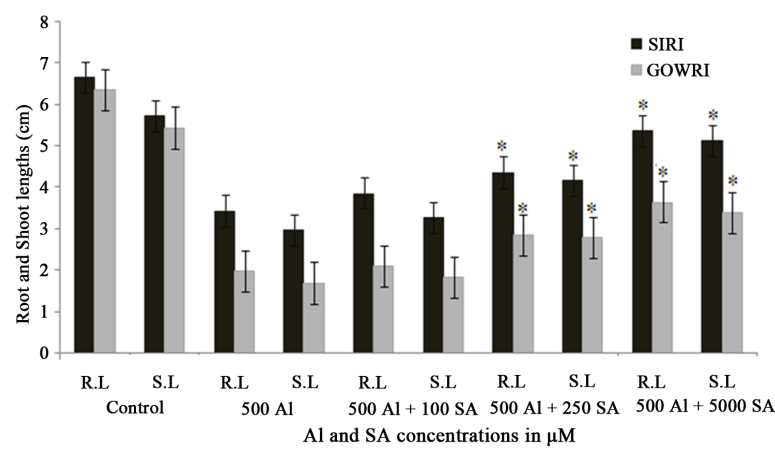

(a)

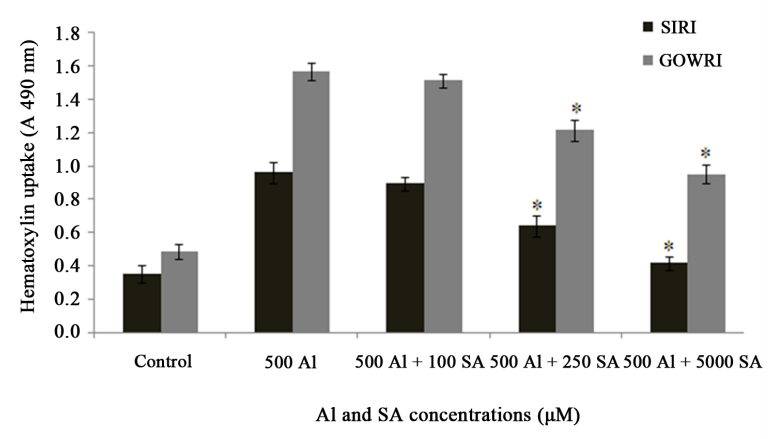

(b)

Figure 1. (a) Effect of $\mathrm{Al}$ and SA on root length (RL) and shoot length (SL) of tomato cultivars; (b) $\mathrm{Al}$ uptake in $\mathrm{Al}$ and SA treated roots of Tomato seedlings. Each value represents the average of six replicates $(n=6) \pm$ standard deviation (SD) and the asterisk indicates a significant difference $(P<0.05)$ between seedlings treated with $\mathrm{Al}$ and both $\mathrm{Al}$ and SA.

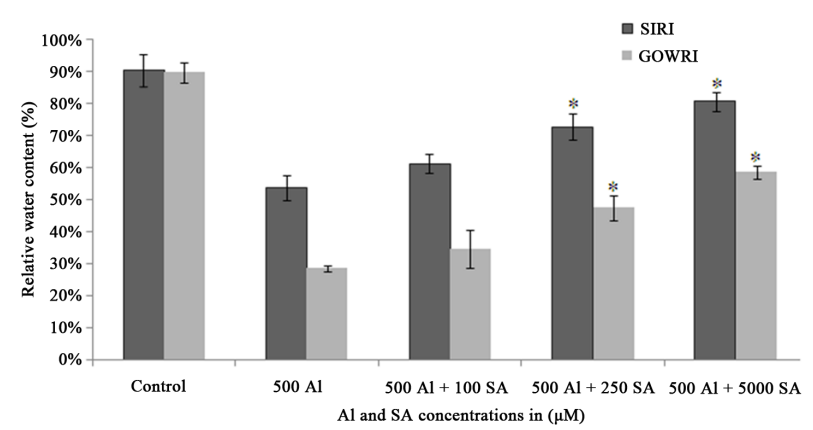

(a)

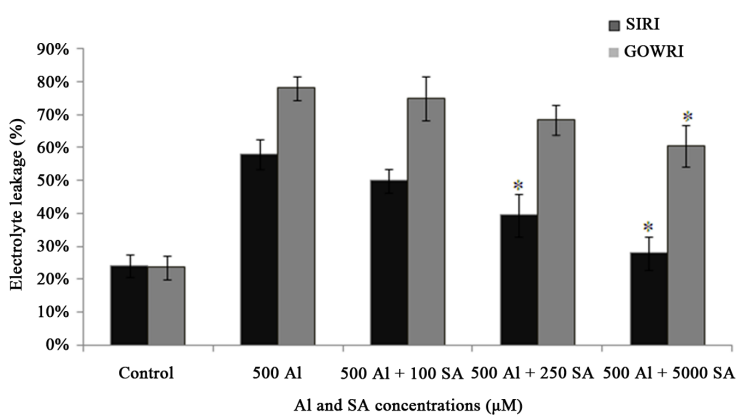

(b)

Figure 2. (a) Effect of Al and SA on relative water content (RWC) in tomato cultivars; (b) Impact of Al and SA on electrolyte leakage in SIRI (Al resistant) and GOWRY (Al-sensitive) seedlings. Each value represents the average of six replicates $(n=6) \pm$ standard deviation (SD) and the asterisk indicates a significant difference $(P<0.05)$ between seedlings treated with $\mathrm{Al}$ and both $\mathrm{Al}$ and $\mathrm{SA}$. 
key biochemical indicators of ROS-mediated damage to cell membranes and to assess the sensitivity of plants to $\mathrm{Al}$ stress as well. In the present study, greater lipid peroxidation was observed in tomato seedlings under $\mathrm{Al}$ stress as evident from 2.0 and 5.0 fold higher MDA content in SIRI and GOWRI respectively, than their respective controls (Figure 3(a)). Further, we assessed the loss of membrane integrity (cell viability) under Al stress by uptake of Evans blue dye through roots. In normal conditions the cell membrane is impermeable to macromolecules such as Evans blue, but, when it undergoes an injury or loses its selective permeability, macromolecules can penetrate it. Thus, the amount of Evans blue entering and binding dead cells reflects the degree of loss of cell membrane integrity and is an estimate of cell death. In our experiments, when compared to control plants, nearly $40 \%$ and $75 \%$ higher uptake of dye was observed respectively in SIRI and GOWRI root tips under Al stress (Figure 3(b)). This indicated a significant loss of root plasma membrane integrity due to Al treatment (Figure 3(b)).

The extent of membrane damage and loss of cell membrane integrity were also estimated by electrolyte leakage from root tissues. Electrical conductivity assay in roots serves as an indicator of ion leakage. Supplementation of $500 \mu \mathrm{M} \mathrm{Al}$ in the treatment solution resulted in significant (55\% and 80\% respectively in SIRI and GOWRI) leakage of solutes through roots of tomato seedlings (Figure 2(b)). However, supplementation of increasing concentration of SA caused considerably reduced membrane damage. This was evident from lesser lipid peroxidation (40\% - 80\%) of membrane components, 50\% - 80\% recovery in cell viability and 50\% - 80\% suppression of electrolyte leakage when compared to their Al-treated plants. In comparison, better recovery from toxic effects of Al was noted in SIRI than GOWRI with SA supplementation. These results suggest that, when compared to SIRI, seedlings of GOWRI have undergone higher lipid peroxidation, loss of membrane integrity and over leakage of electrolytes indicting more damage under Al stress and less recovery with SA

\subsection{Measurement of Glutathione and Proline Contents}

Glutathione is an important antioxidant involved in protection of plant system from ROS or other toxic molecules, resulting in the oxidation of GSH to GSSG. However, when the toxic molecules concentrations exceed the permissible limit, glutathione content itself gets affected. In our study glutathione content declined 1.0 and 2.5 fold respectively in SIRI and GOWRI, over their controls during Al treatment. However, supplementation of 100,250 and $500 \mu \mathrm{M}$ SA to the Al-containing growth medium considerably and dose-dependently improved glutathione content. A recovery of 0.4 - 1.4 fold in glutathione content was observed in SIRI while GOWRI exhibited 0.2 - 1.0 fold (Figure 3(c)), when compared to Al-treated plants. This result indicates a prominent role
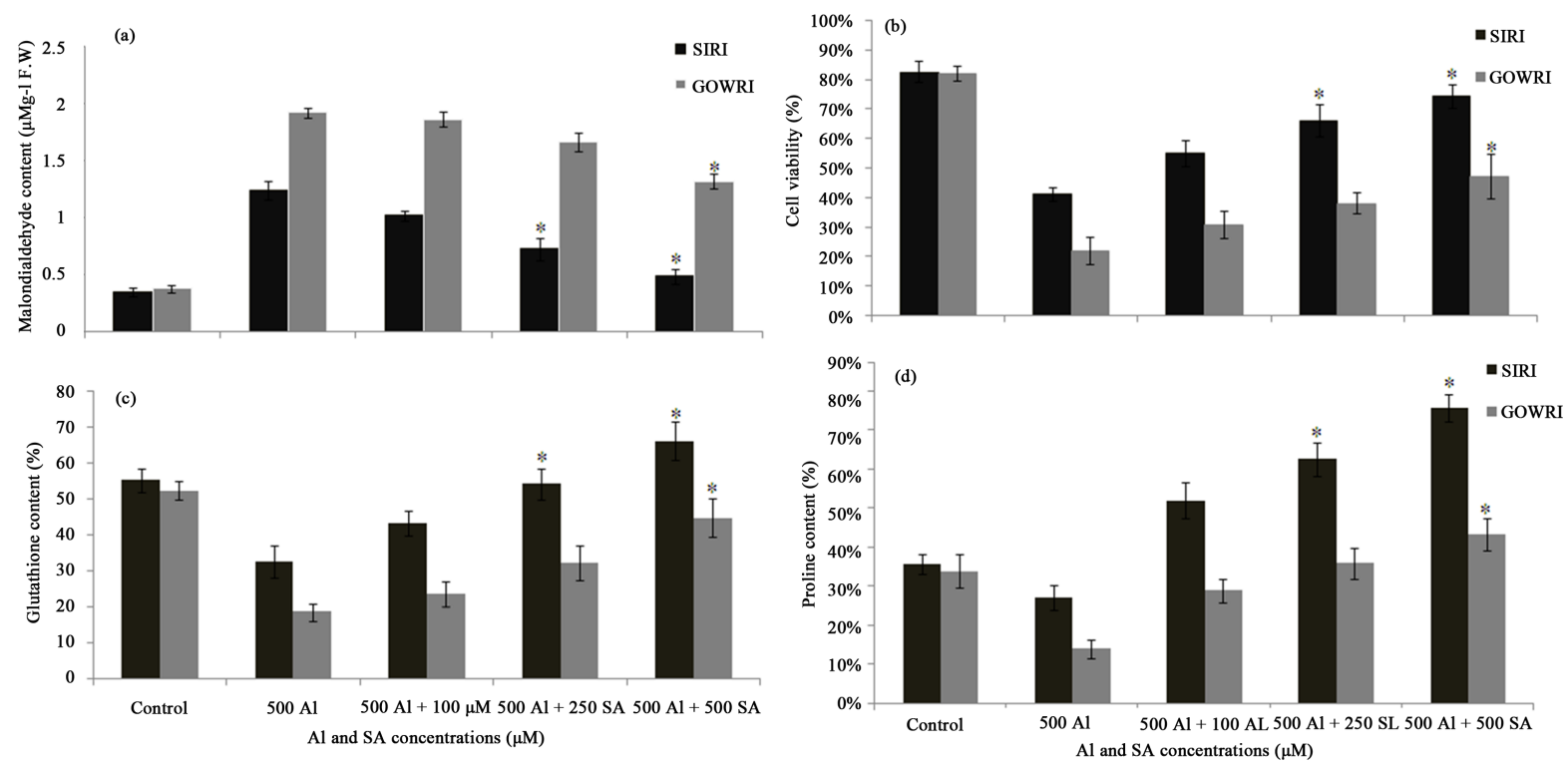

Figure 3. (a) Effect of Al and SA on MDA levels in Tomato seedlings; (b) Cell viability \%; (c) Glutathione content; (d) Proline content. Each value represents the average of six replicates $(n=6) \pm$ standard deviation (SD) and the asterisk indicates a significant difference $(P<0.05)$ between seedlings treated with $\mathrm{Al}$ and both $\mathrm{Al}$ and $\mathrm{SA}$. 
for glutathione in the adaptive response to $\mathrm{Al}$ stress and maintenance of the redox status in physiological conditions.

Proline is considered as a compatible osmolyte produced under various stress conditions and has been suggested to function as a scavenger of hydroxyl radicals, controlling redox homeostasis. In our study proline content decreased 0.5-fold in SIRI and 2.0 fold in GOWRI in the presence of Al when compared to control plants. Supplementation of SA has dose-dependently and significantly increased proline synthesis in both the cultivars (Figure 3(d)). More particularly, with SA supplementation, SIRI exhibited 70\% higher proline content than GOWRI; however no considerable difference was evident in proline content between SIRI and GOWRI cultivars in the absence of Al stress (Figure 3(d)). This data on proline content in SIRI and GOWRI in the presence and absence of SA supported the hypothesis of positive correlation between proline accumulation and $\mathrm{Al}$ tolerance in tomato cultivars.

\subsection{Activities of Antioxidant Enzymes}

In our study the activity of important antioxidant enzymes was measured in both SIRI and GOWRI cultivars in the presence and absence of $\mathrm{Al}$ and SA, to evaluate their role in scavenging ROS. Without $\mathrm{Al}$ treatment, both SIRI and GOWRI leaves exhibited only basal SOD activity, with no significant difference between them. After $500 \mu \mathrm{M} \mathrm{Al}$ treatment, the SOD activity of SIRI and GOWRI increased 1.0 and 2.0 fold respectively over their controls. However, its activity decreased (0.5 - 1.2 fold) in these cultivars when supplemented with SA (Figure 4(a)). This results shows that SIRI was relatively resistant to Al stress than GOWRI, which was evident from lower SOD activity in the presence of $\mathrm{Al}$ and $\mathrm{SA}$, indicating lower $\mathrm{ROS}$ accumulation to scavenge.

Catalase $\left(\mathrm{H}_{2} \mathrm{O}_{2}\right.$ oxidoreductase) is a heme-containing enzyme that catalyzes the dismutation of $\mathrm{H}_{2} \mathrm{O}_{2}$ in to $\mathrm{H}_{2} \mathrm{O}$ and $\mathrm{O}_{2}$. In the present study, CAT activity decreased 0.8 fold in SIRI and 2.0 fold in GOWRI when compared to control plants. With increased supplementation of SA to growth medium, a moderate raise (0.2 - 0.5 fold) in CAT activity was noticed in the tomato cultivars (Figure 4(b)). This suggested that exogenously added SA tried to enhance CAT activity in Al-exposed seedlings there by facilitating dismutation of $\mathrm{H}_{2} \mathrm{O}_{2}$ in to non toxic forms so as to minimize the ROS induced oxidative stress.

Peroxidase is an important ROS scavenging enzyme that uses ascorbate as hydrogen donor to breakdown $\mathrm{H}_{2} \mathrm{O}_{2}$ to form $\mathrm{H}_{2} \mathrm{O}$. No significant change in the activity of peroxidase was observed between tomato cultivars at zero concentration of Al. However at $500 \mu \mathrm{M} \mathrm{Al}$ concentration, POD activity increased 1.0 and 2.0 fold in SIRI

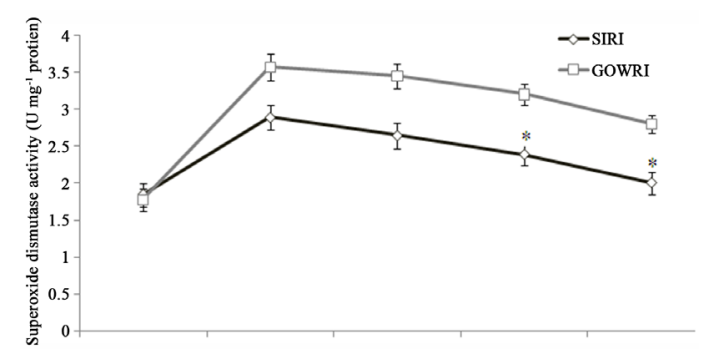

(a)

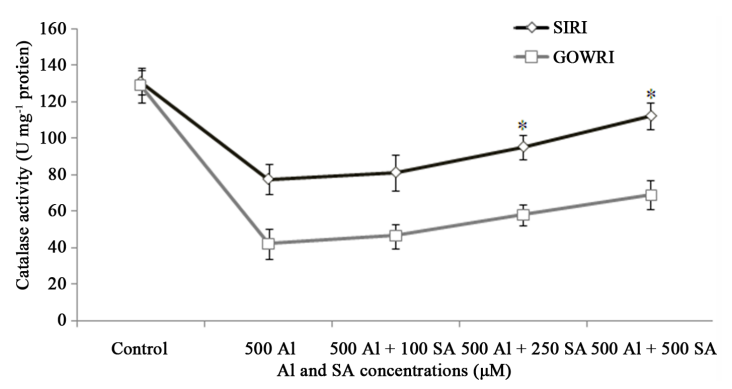

(b)

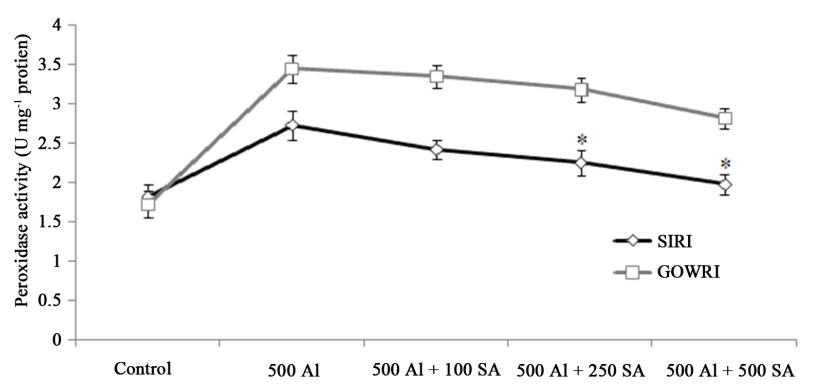

(c)

Figure 4. Effect of Al and SA on enzyme activities of (a) SOD, (b) POD and (c) CAT in tomato cultivars. Each value represents the average of six replicates $(n=6) \pm$ standard deviation $(S D)$ and the asterisk indicates a significant difference $(P<0.05)$ between seedlings treated with $\mathrm{Al}$ and both $\mathrm{Al}$ and $\mathrm{SA}$. 
and GOWRI respectively. Upon supplementation of various concentrations of SA to growth medium, POD activity was restored to near normally in SIRI but GOWRI continued to exhibit 0.5 fold higher activities (Figure 4(c)). The elevated levels of POD activity confirm its active role in efficient conversion of $\mathrm{H}_{2} \mathrm{O}_{2}$ in to $\mathrm{H}_{2} \mathrm{O}$ in tomato cultivars, thus reducing oxidative stress inflicted by $\mathrm{Al}$ stress.

\subsection{DNA Damage}

While no DNA degradation was observed in control seedlings of SIRI and GOWRI, DNA degradation was clearly observed in both the cultivars when exposed to $500 \mu \mathrm{M} \mathrm{Al}$ treatment (Figure 5). However, an increase in DNA damage level was observed in GOWRI compared to SIRI (lane 2 and 7). Supplementation of SA reduced DNA damage in a dose-dependent manner (lanes 3 - 5 and 8 - 10). This results show that SIRI exhibited less DNA damage in the presence of SA and therefore revealed its relatively resistant nature than GOWRI under Al stress.

\section{Discussion}

Soil acidity is an important constraint for plant growth and crop yield. Natural and anthropogenic activities are responsible for growing soil acidity across the world. Al, an abundant metal in the soil, is a major limiting factor of crop productivity in acidic soils. In the present study, the toxic effects of $\mathrm{Al}$ as well as their alleviation by salicylic acid were examined in two tomato cultivars differing in their sensitivity to Al stress. After preliminary screening, cultivars SIRI and GOWRI were selected as Al-resistant and Al-sensitive plants respectively. Two-week old seedlings of these two tomato cultivars were subjected to $500 \mu \mathrm{M}$ Al stress in the presence and absence of SA and evaluated for their physiological and biochemical responses.

Plant growth is the combination of cell division and elongation. The primary effects of $\mathrm{Al}$ on root membrane permeability may appear within a few hours after exposure to $\mathrm{Al}$. In the present study, $\mathrm{Al}$ caused marked reduction in root, shoot length and RWC in GOWRI than SIRI (Figure 1(a) and Figure 1(b) and Figure 2(a)). We also noticed increased $\mathrm{Al}$ uptake under $\mathrm{Al}$ stress. The first symptom of Al toxicity is the inhibition of root elongation associated with uptake of $\mathrm{Al}$, which disturbs the root functions including water and nutrient uptake under $\mathrm{Al}$ stress [1]-[20]. Panda et al. [21] reported that long-term Al treated plants could not uptake water due to the interaction of $\mathrm{Al}$ with root cell nuclei, inhibiting cell division and cytoskeleton formation. It was proposed that in resistant cultivar SIRI, the release of $\mathrm{Al}^{3+}$ binding compounds in to the apoplastic region and at the root tip surface can effectively chelate $\mathrm{Al}^{3+}$, avoiding to some extent its penetration into cells and preventing successive tissue damage [22].

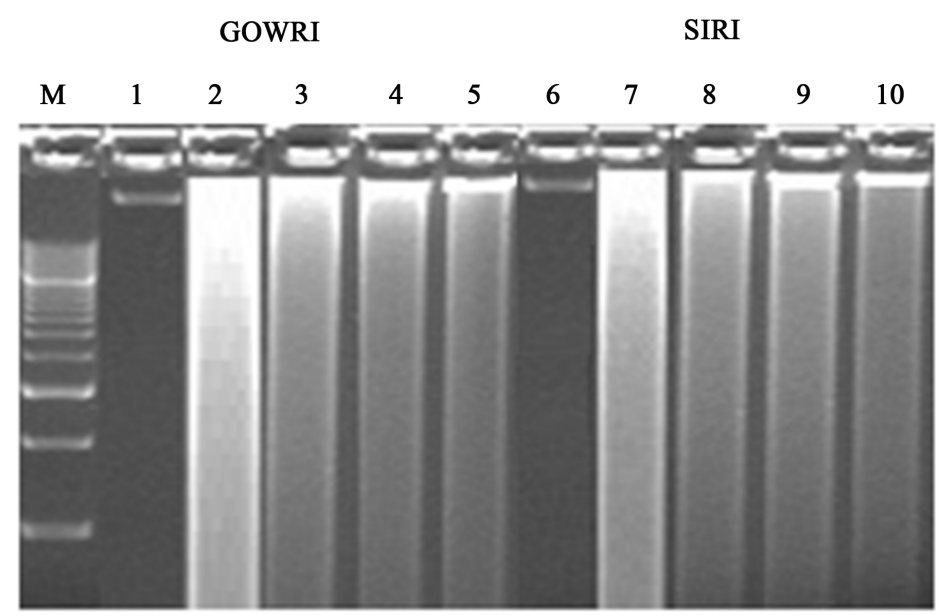

Figure 5. Effect of $\mathrm{Al}$ and SA on DNA damage in tomato seedlings of GOWRI and SIRI. Lane M: 100 bp standard molecular weight marker; Lanes 1 \& 6 are normal controls; Lanes 2 \& 7 represent DNA of GOWRI and SIRI seedlings exposed to $500 \mu \mathrm{M} \mathrm{Al}$ concentration. Lanes 3 - 5 and 8 - 10 represent DNA of GOWRI and SIRI seedlings grown in Al-containing solution supplemented with 100,250 and $500 \mu \mathrm{M}$ of SA respectively. 
SA-treated seedlings showed significant decrease in Al uptake by roots (Figure 4) due probably to the exclusion or detoxification mechanism. Supplementation of SA may lead to increase in the concentration of solutes in the cell. This may lead to an increase in the uptake and retention of water that aids in maintenance of higher RWC content and osmotic balance resulting in improved growth under Al stress. Similar results of reduced uptake of $\mathrm{Al}$ and $\mathrm{Cd}$ by salicylic acid were reported in rice, Cassia tora and maize [23] [24]. In plant growth experiments, the improved plant growth noticed with SA supplementation explains the role of SA to enhance auxin mediated root elongation. It was reported that during salicylic acid treatment the activity of Al transporters was found to be lower. SA was also proposed to facilitate effective sequestration of excess $\mathrm{Al}$ ions in to vacuoles. Our results are consistent with the published reports. A recent study by Nagasubramaniam et al. [25] demonstrated that SA increased plant height and crop growth in baby corn. SA could augment physiological, biochemical and molecular process involved in root growth such as hydrolysis, enzymes activation and protrusion [26]. Supplying of exogenous SA alleviated $\mathrm{NaCl}$-induced changes including root growth and metabolism in Arabidopis and Matricaria [27] [28]. SA supplementation also mitigated Al-induced changes in root growth, RWC and electrolyte leakage in Pisum sativum. Previous studies have shown the involvement of SA in regulating growth processes such as stimulation of root formation in young shoots of ornamental plants.

Reactive oxygen species are involved in the peroxidation of unsaturated fatty acids present in membranes leading to production of lipid peroxides and MDA under Al toxicity in cereals and legumes [6]. Our results showed that, in the absence of SA, high MDA content, more of electrolyte leakage and loss of membrane integrity was noted in both the tomato cultivars under Al stress (Figure 2(b), Figure 3(a) and Figure 3(b)). Tamas et al. [29] showed that enhanced ROS generation caused increased electrolyte leakage and decreased cell viability by the Evans blue staining method. Changes in the cell-membrane permeability and electrolyte leakage of roots due to $\mathrm{Al}$ treatment were also previously reported in pea roots [30]. Enhanced lipid peroxidation and electrolyte leakage were reported in Oryza sativa, Brassica pekinensis and Hordeum vulgare exposed to $\mathrm{Al}$ and heavy metals [31]. Al stressed tomato seedlings when supplemented with SA acid displayed lower electrolyte leakage, reduced lipid peroxidation and plasma membrane integrity (Figure 2(a), Figure 3(a) and Figure 3(b)) which could have been possible by suppression of $\mathrm{Al}$ uptake and up regulation of antioxidant systems against Al-induced oxidative stress. Similar recovery effect of SA on membrane damage was observed under Al induced oxidative stress in Fagopyrum esculentum and Oryza sativa [32]-[38].

Glutathione is a very important soluble antioxidant, because it protects many cellular components under oxidative stress. It plays a vital role in the antioxidant defense system as well as the glyoxalase system by acting as a substrate or cofactor for certain enzymes. In our experiment, GSH content was substantially reduced in tomato seedlings at $500 \mu \mathrm{M} \mathrm{Al}$ concentration. However, with exogenous application of SA to the Al solution, increase in glutathione content was observed (Figure 3(c)). The increased GSH content might be due to the increase in GR activity as well as higher GSH biosynthesis. The improvement in GSH content indicates a clear role of SA in producing non-enzymatic antioxidant. It is suggested that the GSH/GSSG ratio, is an indicative of the cellular redox balance, may be involved in ROS perception [33]. Similar observations of SA mediated amelioration of drought stress was reported in mustard, mung bean by improved antioxidant system [34]. The GSH cycle is the major defense system against ROS in chloroplasts, cytosol, mitochondria, peroxisomes and apoplasts. Although GSH is involved in numerous metabolic functions, it's most notable role is in eliminating the ROS produced during oxidative stress. The adaptive responses of plants to increased ROS formation are measured at least in part, by changes in cell concentrations of GSH [35].

Proline is an important osmo-protectant that plays a vital role in osmotic balancing during drought and related stress conditions. It was reported to protect sub-cellular structures, enzymes and more over it increases cellular osmolarity (turgor pressure) that provide the turgor necessary for cell expansion under stress conditions. In this study, exogenous application of $(100,250$ and $500 \mu \mathrm{M})$ SA significantly increased proline content in both the tomato cultivars under Al stress, with the highest proline synthesis being recorded in SIRI (Figure 3(d)). Previous studies by Hayat et al. [36] demonstrated increased plant proline content after supplementation with SA. Proline is considered as the only osmolyte implicated in scavenging singlet oxygen and free radicals including hydroxyl ions, and there by stabilizes proteins, DNA, as well as other membrane structures [37]. Proline accumulation is reported to activate antioxidant defense mechanisms and also acts as a source of carbon, nitrogen and energy during and recovery from stresses [38]. Therefore, higher proline accumulation is often related with enhanced Al tolerance of plant species.

Production of ROS is promoted under various environmental stresses. ROS causes oxidative damage to lipids, proteins and nucleic acids in the cell. The most effective antioxidative enzyme in preventing ROS induced cel- 
lular oxidative damage is SOD which catalyzes the conversion of $\mathrm{O}_{2}^{-}$to $\mathrm{H}_{2} \mathrm{O}_{2}$, whereas CAT scavenges $\mathrm{H}_{2} \mathrm{O}_{2}$ and peroxidase uses $\mathrm{H}_{2} \mathrm{O}_{2}$ for the oxidation of various inorganic and organic substrates; thus SOD, CAT and peroxidases are regarded as the major antioxidant enzymes present in plant cells. In our study, SOD activity showed 1 - 2 fold increase over their controls (Figure 4). SOD is a key enzyme of antioxidantive defense system and helps in removal of overproduced $\mathrm{O}_{2}^{-}$in the stressful conditions. An increase in SOD activity is often correlated with increased rate of removal of $\mathrm{O}_{2}^{-}$from cells in order to keep $\mathrm{O}_{2}^{-}$level under control. Increase in $\mathrm{O}_{2}^{-}$level under $\mathrm{Al}$ stress could necessitate higher SOD activity in Al-treated plants [39]. Among the enzymes involved in $\mathrm{H}_{2} \mathrm{O}_{2}$ removal, the activity of CAT declined 0.8 - 2.0 fold in Al-treated seedlings. In another study, $\mathrm{CAT}$ activity of garlic roots declined when exposed to $\mathrm{Pb}$, indicating the inactivation of enzyme due to accumulation of $\mathrm{H}_{2} \mathrm{O}_{2}$ induced by $\mathrm{Pb}$ [40]. When SA was supplemented to Al containing medium, it caused fall in SOD activitiy but stimulated Al-led rise in CAT activity. This suggests that SA help in alleviation of Al induced damage by adequately maintaining the activity levels of the antioxidative enzymes. SA appeared to be more effective in suppressing $\mathrm{Al}$ induced increase in SOD activity in the seedlings. A low level of $\mathrm{O}_{2}^{-}$with a concomitant lower SOD activity in SA + Al treated seedlings, suggests that SA suppresses the production of $O_{2}^{-}$by a protective mechanism which in turn results in relatively low level of SOD activity. CAT is proposed to be a SA receptor. After binding with SA, CAT becomes inactive leading to $\mathrm{H}_{2} \mathrm{O}_{2}$ accumulation in plant cells [41]. However, in our studies, in Al + SA treated plants, CAT activity showed a gradual increase with rise in SA concentration in the growth medium. SIRI showed maximum recovery in its CAT activity while GOWRI could not.

POD is another important enzyme involved in removal of $\mathrm{H}_{2} \mathrm{O}_{2}$. Its activity increased 1 - 2 fold in $\mathrm{Al}$ treated tomato seedlings compared to controls. PODs are regarded as stress enzymes and the activity of peroxidases increases under abiotic stresses including Al toxicity [42]. Restoration of POD activity to the normal level in tomato plants appears to be a characteristic feature of SA in Al treated seedlings. Spraying the drought stressed plants of Lycopersicon esculentum with SA enhanced the activities of antioxidative enzymes SOD, APX and CAT and protected the plants against oxidative damage [36]. Treatment with SA alleviated mercury toxicity in alfalfa plants by preventing oxidative stress in roots and increasing the activities of NADH-oxidase, APX and POD [43].

Al-induced DNA damage observed in tomato seedlings could be either due to direct interference of $\mathrm{Al}$ with important ions like $\mathrm{Mg}^{2+}, \mathrm{P}, \mathrm{Ca}^{2+}$ etc. that have a pivotal role in DNA structure and integrity [44]. Wallace and Anderson [45] suggested that moderate levels of Al treatment caused rapid inhibition of root elongation as well as inhibition of DNA synthesis but, higher level of Al might lead to degradation of DNA by apoptosis like cell death in certain wheat cultivars. Alternatively, Al-induced DNA damage was presumed to be the consequence of direct attack of oxygen free radicals on DNA strands [46]. This view gets support from our study which showed enhanced lipid peroxidation under $\mathrm{Al}$ stress. Katsuhara and Kawasaki [47] reported that variations in cytoplasmic $\mathrm{Ca}^{2+}$ levels might activate certain $\mathrm{Ca}^{2+}$-dependent endogenous proteases to cleave chromatic DNA at the linker site between nucleosomes resulting in fragmentation of DNA. Our results may be related to the previous findings of peitsch et al. [48], who observed DNA degradation and eventual cell death in mouse thymocytes under $\mathrm{Al}$ stress. In the present study, $\mathrm{Al}$ induced fragmentation of DNA indicates that DNA of GOWRI was more sensitive to Al toxicity than SIRI. Thus, Al mediated oxidative stress resulted in enhanced lipid peroxidation of membranes and elevated activities of SOD and POD and ultimately DNA damage.

It is proposed that SA is involved in amelioration of Al-induced toxicity in tomato seedlings majorly through auxin mediated root elongation that aids in better uptake of water and nutrients. SA is thought to alleviate toxic effects of $\mathrm{Al}$ by inhibiting $\mathrm{Al}$ uptake by chelation and effective sequestration of accumulated $\mathrm{Al}$ into vacuoles of the cell so that ionic and osmotic balance could be attained. Rise in Glutathione content, restoration of altered antioxidant enzyme activities and reduced LPO by SA reveals its protective role against ROS-induced damage under $\mathrm{Al}$ stress. SA mediated rise in proline content augments osmotic protection against Al-induced water deficit in tomato seedlings. Finally, protection of DNA from degradation under Al stress confirms the role of SA as an efficient growth regulator with diversified roles in alleviating $\mathrm{Al}$ induced toxicity. However, the exact mechanisms still remain to be elucidated. Based on our findings it can be concluded that SA effectively alleviates $\mathrm{Al}$ toxicity in tomato seedlings and SIRI is a relatively resistant cultivar to $\mathrm{Al}$ stress compared to GOWRI.

\section{Acknowledgements}

The authors thankfully acknowledge the financial assistance received from the University Grants Commission, New Delhi. 


\section{References}

[1] Kochian, L.V., Pineros, M.S. and Hoekenga, O.A. (2005) The Physiology, Genetics and Molecular Biology of Plant Aluminum Resistance and Toxicity. Plant and Soil, 274, 175-195. http://dx.doi.org/10.1007/s11104-004-1158-7

[2] Barcelo, J. and Poschenrieder, C. (2002) Fast Root Growth Responses, Root Exudates and Internal Detoxification as Clues to the Mechanisms of Aluminum Toxicity and Resistance. Environmental and Experimental Botany, 48, 75-92. http://dx.doi.org/10.1016/S0098-8472(02)00013-8

[3] Ma, J.F. (2007) Syndrome of Aluminum Toxicity and Diversity of Aluminum Resistance in Higher Plants. International Review of Cytology, 264, 225-252. http://dx.doi.org/10.1016/S0074-7696(07)64005-4

[4] Jain, L.Y., Ya, Y.L., Yue, J.Z., Shan, Z., Yun, R.W., Ping, W. and Shao, J.Z. (2008) Cell Wall Polysaccharides Are Specifically Involved in the Exclusion of Aluminum Form the Rice Root Apex. Plant Physiology, 146, 602-611.

[5] Ribeiro, C., Cambraia, J., Peixoto, P.H.P. and Junior, E.M.F. (2012) Antioxidant System Response Induced by Aluminum in Two Rice Cultivars. Brazilian Journal of Plant Physiology, 24, 2. http://dx.doi.org/10.1590/S1677-04202012000200004

[6] Sharma, P., Bhushanm, A., Dubey, R.S. and Pessarakli, M. (2012) Reactive Oxygen Species, Oxidative Damage and Antioxidant Defense Mechanism in Plants under Stressful Conditions. Journal of Botany, 26, Article ID: 217037. http://dx.doi.org/10.1155/2012/217037

[7] Zhu, X.F., Lei, G., Wang, Z.W., Shi, Y.Z., Braam, J., Li, G.X. and Zheng, S.J. (2013) Coordination between Apoplastic and Symplastic Detoxification Confers Plant Aluminum Resistance. Plant Physiology, 162, 1947-1955. http://dx.doi.org/10.1104/pp.113.219147

[8] Pandey. P., Srivastava, R.K. and Dubey, R.S. (2013) Salicylic Acid Alleviates Aluminum Toxicity in Rice Seedlings Better than Magnesium and Calcium by reducing Aluminum Uptake, Suppressing Oxidative Damage and Increasing Antioxidative Defense. Ecotoxicology, 22, 656-670. http://dx.doi.org/10.1007/s10646-013-1058-9

[9] Hoagland, D.R. and Arnon, D.I. (1950) The Water Culture Method for Growing Plants Without Soil. California Agriculture Experimental Station, 347.

[10] Ownby, J.D. (1993) Mechanism of Reaction of Hematoxylin with Aluminum-Treated Wheat Roots. Physiologia Plantarum, 87, 371-380. http://dx.doi.org/10.1111/j.1399-3054.1993.tb01744.x

[11] Lin, C.Y., Chen, Y.M. and Key, J.L. (1985) Solute Leakage in Soybean Seedlings under Various Heat Shock Regimes. Plant and Cell Physiology, 26, 1493-1498.

[12] Heath, R.L. and Packer, L. (1986) Photoperoxidation in Isolated Chloroplasts. I. Kinetics and Stoichiometry of Fatty Acid Peroxidation. Archives of Biochemistry and Biophysics, 125, 189-198. http://dx.doi.org/10.1016/0003-9861(68)90654-1

[13] Baker, C.J. and Mock, N.M. (1994) An Improved Method for Monitoring Cell Death in Cell Suspension and Leaf Disc Assays Using Evans Blue. Plant Cell, Tissue and Organ Culture, 39, 7-12. http://dx.doi.org/10.1007/BF00037585

[14] Anderson, M.E. (1985) Determination of Glutathione and Glutathione Disulfide in Biological Samples. Methods in Enzymology, 113, 548-555. http://dx.doi.org/10.1016/S0076-6879(85)13073-9

[15] Bates, L.S., Waldren, R.P. and Teari, I.D. (1973) Rapid Determination of Free Proline for Water Stress Studies. Plant and Soil, 39, 205-207. http://dx.doi.org/10.1007/BF00018060

[16] Bayer, C. and Fridovich, I. (1987) Superoxide Dismutase: Improved Assays and Applicable to Acrylamide Gels. Analytical Biochemistry, 44, 276-287.

[17] Nakano, Y. and Asada, K. (1981) Hydrogen Peroxide Is Scavenged by Ascorbate-Specific Peroxidase in Spinach Chloroplasts. Plant and Cell Physiology, 22, 867-880.

[18] Aebi, H. (1984) Catalase in Vitro. Methods in Enzymology, 105, 121-126. http://dx.doi.org/10.1016/S0076-6879(84)05016-3

[19] Jena, K.K. and Kochert, G. (1991) Restriction Fragment Length Polymorphism Analysis of CCDD Genome Species of the Genus Oryza sativa L. Plant Molecular Biology, 16, 831-839. http://dx.doi.org/10.1007/BF00015075

[20] Riberio, M.A.Q., Almeda, A.A.F., Mielke, M.S., Gomes, F.P., Pires, M.V. and Baligar, V.C. (2013) Aluminum Effects on Growth, Photosynthesis, and Mineral Nutrition of CACAO Genotypes. Journal of Plant Nutrition, 36, 1161-1179. http://dx.doi.org/10.1080/01904167.2013.766889

[21] Panda, S.K., Baluska, F. and Matsumoto, H. (2009) Aluminum Signaling in Plants. Plant Signaling and Behavior, 4, 529-597. http://dx.doi.org/10.4161/psb.4.7.8903

[22] Alvim, M.N., Ramos, F.T., Olivera, D., Isaias, R.M.S. and Franca, M.G.C. (2012) Aluminum Localization and Toxicity Symptoms Related to Root Growth Inhibition in Rice (Oryza sativa L.) Seedlings. Journal of Biosciences, 37, 10791088. http://dx.doi.org/10.1007/s12038-012-9275-6 
[23] Panda, S.K. and Patra, H.K. (2007) Effect of Salicylic Acid Potentiates Cadmium-Induced Oxidative Damage in Oryza sativa L. Leaves. Acta Physiologiae Plantarum, 29, 567-575. http://dx.doi.org/10.1007/s11738-007-0069-7

[24] Krantev, A., Yordanova, R., Janda, T., Szalai, G. and Popova, L. (2008) Treatment with Salicylic Acid Decreases the Effect of Cadmium on Photosynthesis in Maize Plants. Journal of Plant Physiology, 165, 920-931. http://dx.doi.org/10.1016/j.jplph.2006.11.014

[25] Nagasubramaniam, A., Pathmanabhan, G. and Mallika, V. (2007) Studies on Improving Production Potential of Baby corn with Foliar Spray of Plant Growth Regulators. Annual Review of Plant Physiology and Plant Molecular Biology, 21, 154-157.

[26] Farooq, M., Aziz, T., Wahid, A., Lee, D.J. and Siddique, K.H.M. (2009) Chilling Tolerance in Maize: Agronomic and Physiological Approaches. Crop \& Pasture Science, 60, 501-516. http://dx.doi.org/10.1071/CP08427

[27] Kovacik, J., Klejdus, B., Hedbavny, J. and Backor, M. (2009) Salicylic Acid Alleviates NaCl-Induced Changes in the Metabolism of Matricaria chamomilla Plants. Ecotoxicology, 18, 544-554. http://dx.doi.org/10.1007/s10646-009-0312-7

[28] Jayakannan, M., Bose, J., Babourina, O., Rengel, Z. and Shabala, S. (2013) Salicylic Acid Improves Salinity Tolerance in Arabidopsis by Restoring Membrane Potential and Preventing Salt-Induced $\mathrm{K}^{+}$Loss via a GORK Channel. Journal of Experimental Botany, 64, 2255-2268. http://dx.doi.org/10.1093/jxb/ert085

[29] Tamas, L., Budikova, S., Simonovicova, M., Huttova, J., Siroka, B. and Mistrick, I. (2006) Rapid and Simple Method for Al-Toxicity Analysis in Emerging Barley Roots during Germination. Biologia Plantarum, 50, 87-93. http://dx.doi.org/10.1007/s10535-005-0079-5

[30] Yamamoto, Y., Kobayashi, Y. and Matsumoto, H. (2001) Lipid Peroxidation Is an Early Symptom Triggered by Aluminum but Not the Primary Cause of Elongation Inhibition in Pea Roots. Plant Physiology, 125, 199-208. http://dx.doi.org/10.1104/pp.125.1.199

[31] Xiong, Z.T. and Wang, H. (2005) Copper Toxicity and Bioaccumulation in Chinese Cabbage (Brassica pekinensis Rupr.). Environmental Toxicology, 20, 188-194. http://dx.doi.org/10.1002/tox.20094

[32] Shen, R., Ma, J., Kyo, M. and Iwashita, T. (2002) Compartmentalization of Aluminum in Leaves of an Al Accumulator, Fagopyrum esulentum Moench. Planta, 215, 394-398. http://dx.doi.org/10.1007/s00425-002-0763-Z

[33] Shao, H.B. and Chu, L.Y. (2005) Plant Molecular Biology in China: Opportunities and Challenges. Plant Molecular Biology Reporter, 23, 345-358.

[34] Liu, J.P., Piñeros, M.A. and Kochian, L.V. (2014) The Role of Aluminum Sensing and Signaling in Plant Aluminum Resistance. Journal of Integrative Plant Biology, 56, 221-230. http://dx.doi.org/10.1111/jipb.12162

[35] Noctor, G., Veljovic-Jovanovic, S., Driscoll, S., Novitskaya, L. and Foyer, C.H. (2002) Drought and Oxidative Load in the Leaves of C3 Plants: A Predominant Role for Photorespiration. Annals of Botany, 89, 841-850. http://dx.doi.org/10.1093/aob/mcf096

[36] Hayat, S., Hasan, S.A., Fariduddin, Q. and Ahmad, A. (2008) Growth of Tomato (Lycopersicon esculentum) in Response to Salicylic Acid under Water Stress. Journal of Plant Science, 3, 297-304.

[37] Kavi Kishor, P.B., Sangam, S., Amrutha, R.N., Sri Laxmi, P., Naidu, K.R., Rao, K.R.S.S., Rao, S., Reddy, K.J., Theriappan, P. and Sreenivasulu, N. (2005) Regulation of Proline Biosynthesis, Degradation, Uptake and Transport in Higher Plants: Its Implications in Plant Growth and Abiotic Stress Tolerance. Current Science, 88, 424-438.

[38] Demiral, T. and Türkan, İ. (2005) Comparative Lipid Peroxidation, Antioxidant Defense Systems and Proline Content in Roots of Two Rice Cultivars Differing in Salt Tolerance. Environmental and Experimental Botany, 53, $247-257$. http://dx.doi.org/10.1016/j.envexpbot.2004.03.017

[39] Boscolo, P.R.S., Menossi, M. and Jorge, R.A. (2003) Aluminum Induced Oxidative Stress in Maize. Phytochemistry, 62, 181-189. http://dx.doi.org/10.1016/S0031-9422(02)00491-0

[40] Liu, D.H., Zou, J., Meng, Q.M., Zou, J.H. and Jiang, W.S. (2009) Uptake and Accumulation and Oxidative Stress in Garlic (Allium sativam L.) under Lead Phytotoxicity. Ecotoxicology, 18, 134-143. http://dx.doi.org/10.1007/s10646-008-0266-1

[41] Breusegem, F.V., Vranova, E., Dat, J.F. and Inze, D. (2001) The Role of Active Oxygen Species in Plant Signal Transduction. Plant Science, 161, 405-414. http://dx.doi.org/10.1016/S0168-9452(01)00452-6

[42] Sharma, P. and Dubey, R.S. (2007) Involvement of Oxidative Stress and Role of Antioxidative Defense System in Growing Rice Seedlings Exposed to Toxic Concentrations of Aluminum. Plant Cell Reports, 26, 2027-2038. http://dx.doi.org/10.1007/s00299-007-0416-6

[43] Zhou, Z.S., Guo, K., Elbaz, A.A. and Yang, Z.M. (2009) Salicylic Acid Alleviates Mercury Toxicity by Preventing Oxidative Stress in Roots of Medicago sativa. Environmental and Experimental Botany, 65, 27-34. http://dx.doi.org/10.1016/j.envexpbot.2008.06.001 
[44] Foy, C.D., Chaney, R.L. and White, M.C. (1978) The Physiology of Metal Toxicity in Plants. Annual Review of Plant Physiology, 29, 511-566. http://dx.doi.org/10.1146/annurev.pp.29.060178.002455

[45] Wallace, S.U. and Anderson, I.C. (1984) Aluminum Toxicity and DNA Synthesis in Wheat Roots. Agronomy Journal, 76, 5-8. http://dx.doi.org/10.2134/agronj1984.00021962007600010002x

[46] Ezaki, B., Gadner, R.C., Ezaki, Y. and Matsumoto, H. (2000) Expression of Aluminum-Induced Genes in Transgenic Arabidopsis Plants Can Ameliorate Al Stress and/or Oxidative Stress. Plant Physiology, 122, 657-666. http://dx.doi.org/10.1104/pp.122.3.657

[47] Katsuhara, M. and Kawasaki, T. (1996) Salt Stress Induced Nuclear and DNA Degradation in Meristematic Cells of Barley Roots. Plant and Cell Physiology, 79, 283-288.

[48] Peitsch, M.C., Muller, C. and Tschopp, J. (1993) DNA Fragmentation during Apoptosis Is Caused by Frequent SingleStrand Cuts. Nucleic Acids Research, 21, 4206-4209. http://dx.doi.org/10.1093/nar/21.18.4206 
Scientific Research Publishing (SCIRP) is one of the largest Open Access journal publishers. It is currently publishing more than 200 open access, online, peer-reviewed journals covering a wide range of academic disciplines. SCIRP serves the worldwide academic communities and contributes to the progress and application of science with its publication.

Other selected journals from SCIRP are listed as below. Submit your manuscript to us via either submit@scirp.org or Online Submission Portal.
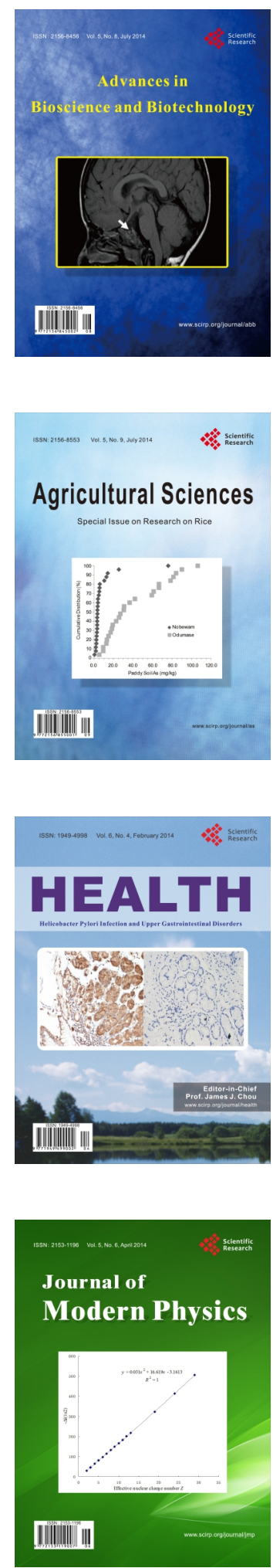
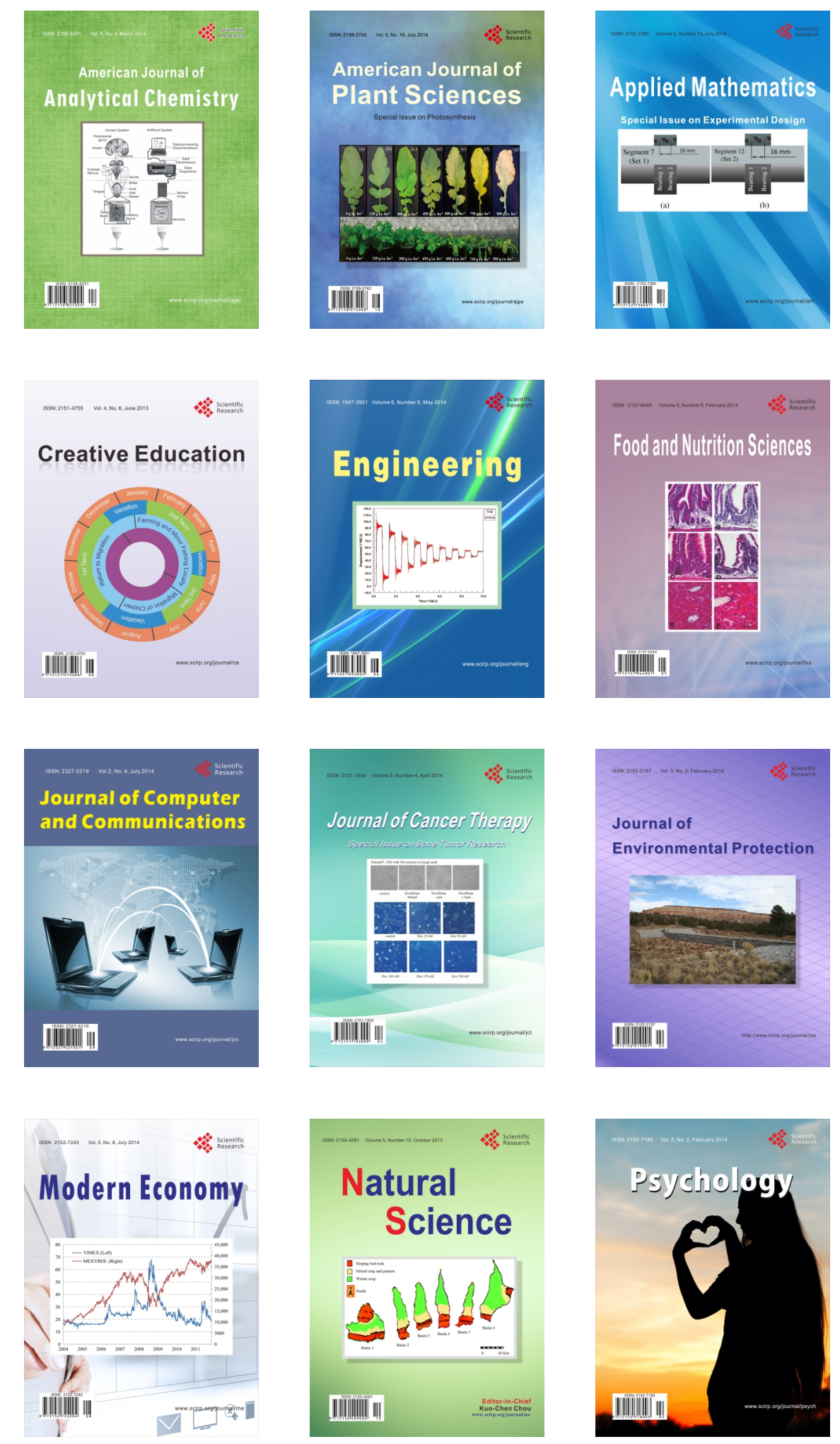